\title{
Mixed Alkyltrimethylammonium-Alkylcarboxylate Surfactants Systems: A Potential Anti-Proliferation Agent for MDA-MB-231 Cancer Cell Line
}

Huei Lim ( $\sim$ limwen@mpob.gov.my )

Malaysian Palm Oil Board

Shuang Yong

Universiti Putra Malaysia

Yee Phang

Universiti Putra Malaysia

Hock Chuah

University of Malaya

Noorjahan Alitheen

Universiti Putra Malaysia

\section{Research Article}

Keywords: alkyltrimethylammonium-alkylcarboxylate surfactants systems, catanionic, cytotoxicity, withcatanionic, tocotrienol rich fraction

Posted Date: December 8th, 2020

DOl: https://doi.org/10.21203/rs.3.rs-116419/v1

License: (c) (1) This work is licensed under a Creative Commons Attribution 4.0 International License.

Read Full License 
Mixed alkyltrimethylammonium-alkylcarboxylate Surfactants Systems: A Potential Anti-Proliferation Agent for MDA-MB-231 Cancer Cell Line

Xiou Shuang Yong ${ }^{1,2}$, Wen Huei Lim²*, Lai Yee Phang ${ }^{1}$, Noorjahan Banu Alitheen ${ }^{1}$ \& Cheng Hock Chuah ${ }^{3}$

${ }^{1}$ Faculty of Biotechnology and Biomolecular Sciences, Universiti Putra Malaysia, 43400 UPM Serdang, Selangor, Malaysia.

${ }^{2}$ Advanced Oleochemical Technology Division (AOTD), Malaysia Palm Oil Board (MPOB), 6, Persiaran Institusi, Bandar Baru Bangi, 43000 Kajang, Selangor, Malaysia.

${ }^{3}$ Unit of Research on Lipids (URL), Chemistry Department, Faculty of Science, University of Malaya, 50603 Kuala Lumpur, Malaysia.

*Correspondence email: limwen@mpob.gov.my 


\begin{abstract}
Series of catanionic based alkyltrimethylammonium-alkylcarboxylate surfactants systems having different degree of alkyl chain length asymmetry were prepared and tested for their cytotoxicity against both fibroblast 3T3 and breast cancer MDA-MB231 cell lines. Catanionic surfactant with the highest alkyl chain length possessed significant potent cytotoxicity, with a half maximal inhibitory concentration $\left(\mathrm{IC}_{50}\right)$ of $4.04 \pm 0.06 \mu \mathrm{M}$ on MDA-MB-231 cell line. Combination of anti-cancer agent (tocotrienol rich fraction,TRF; and curcumin, respectively)with the catanionic at different weight ratios was found to exert lower cytotoxicity on both cell lines as compared to the treated cells with catanionic only. Noticeably, combination of TRF withcatanionic showed higher anti-cancer activities than the incorporation of curcumin with catanionic (resulted low $\mathrm{IC}_{50}$ value). Combination index $(\mathrm{CI})$ of both anti-cancer agent (TRF and curcumin) and catanionic mixtures indicated antagonistic effect (more than 1), respectively, which may explained catanionic surfactant having long alkyl chain length has the potential to act as anti-cancer agent in its pristine form and less effective with other anti-cancer agents combination.
\end{abstract}

\title{
Introduction
}

As it is widely known, surface active agents or surfactants having unique properties are been enormously utilized in cosmetic and personal care, chemical processes as well as health and pharmaceutical sectors ${ }^{1}$. Apart from the common classes of surfactants (anionic, cationic, nonionic and zwitterionic), there is a new class of surfactant known as catanionic surfactants that are produced from mixing of two oppositely charged ionic surfactants at equimolar ratio ${ }^{2}$. This type of surfactant exhibited very interesting properties and unique self-aggregation behaviour into 
various aggregates such as vesicles, micelles, hollow icosahedra and planar bilayers 3-5

Interestingly, a recent review highlighted that the vesicles formed in catanionic surfactants have been correlated with anti-cancer activities in vitro ${ }^{6}$, representing a useful finding for pharmaceutical industries. Treatment with catanionic surfactant vesicles produced from sodium dodecylsulfate and hexadecyltrimethylammonium bromide $\left(\mathrm{TA}_{16}\right)$ induced apoptosis in murine macrophage-like cells but no apoptosis occurred in normal cells ${ }^{7}$. The cell proliferation of cancer cells was much more inhibited than that of normal mouse fibroblast cells when treated with catanionic surfactant vesicles, this was explained by different intrinsic cell membrane permeability of cancer cells in relative to normal cells ${ }^{8}$. Besides that, synthesis of chlorambucil prodrug-containing catanionic vesicles that acted as both carrier and active ingredients at the same time exhibited desirable prolonged drug release and enhanced anti-cancer activities ${ }^{3}$. On the other hand, catanionic solid lipid nanoparticles constructed from catanionic microemulsion efficiently transported chemotherapy drug across blood brain barrier for the treatment of malignant brain tumour in central nervous system ${ }^{9,10}$. Novel catanionic microemulsion containing curcumin displayed higher cytotoxicity in vitro and effectively suppressed tumour growth in vivo through intravenous or oral administrations ${ }^{11}$. Further studies are required to support the anti-cancer activities of catanionic surfactants.

Cancer is a disease with immense public health significance suffered by over millions of patients in the world. Breast cancer is the most frequent invasive 
cancer among women in both developed and developing countries ${ }^{12}$. Breast cancer is a highly metastatic cancer which is capable to spread from one site to another site very rapidly. Triple negative breast cancer accounts for $15 \%$ to $20 \%$ of all breast cancers ${ }^{13}$. The treatment for this highly invasive triple negative breast cancer is very challenging as there is still lacking of targeted treatment site for targeted therapy and available targeted therapeutic agent ${ }^{14}$. Furthermore, adverse effects of cancer treatment and anti-cancer drugs that damages both tumour and normal cells at the same time still remained unresolved ${ }^{15}$. A recent review concluded that $70 \%$ of articles reported enhanced chemotherapy efficiency with the presence of antioxidants 15. This makes antioxidants such as tocotrienol, quercetin, curcumin, carotene, vitamin C, glutathione, coenzyme Q10 and selenium gaining popularity in anticancer researches ${ }^{15-18}$.

Other than that, hexadecanoic acid $\left(\mathrm{C}_{16}\right)$ and octadecanoic acid $\left(\mathrm{C}_{18}\right)$ which are found abundantly in palm oil fractions were discovered to have anti-cancer activities ${ }^{19-21} \cdot \mathrm{C}_{16}$ and $\mathrm{C}_{18}$ were found to inhibit the colony-forming ability of certain cancer cells in vitro and inhibit tumour development in vivo ${ }^{22-24}$, but not the healthy normal fibroblasts in dose-dependent manner ${ }^{22}$. Studies showed the inhibition of cancer cell proliferation of $\mathrm{C}_{16}$ and $\mathrm{C}_{18}$ was caused by apoptosis ${ }^{19,20}$. However, another study demonstrated $\mathrm{C}_{18}$ inhibited cancer cell proliferation by inhibiting cell adhesion that involved a laminin integrin receptor mechanism ${ }^{25}$. Since carboxylic acids were insoluble in aqueous, limited studies focused on anti-cancer activities of carboxylic acids. Carboxylic acids have been employed as biodegradable surfactants reacted with drugs to form catanionic vesicles for drug delivery systems ${ }^{26}$. 
So far, involvement of palm-based carboxylic acids and quaternary ammonium surfactants in catanionic surfactants is scarcely reported and has not been investigated extensively. Additionally, limited studies reported in vitro cytotoxicity of catanionic surfactant. Cytotoxicity evaluation of starting materials including surfactants was essential as a beginning step in cancer research studies. In the present study, cytotoxicity of catanionic surfactants systems produced from mixtures of carboxylic acids and alkyltrimethylammonium bromide $\left(\mathrm{TA}_{m}\right)$ or alkyltrimethylammonium chloride $\left(\mathrm{TAC}_{m}\right)$ on both mouse embryo fibroblast and human breast cancer cell lines were investigated. Combination of selected catanionic surfactant with tocotrienol rich fraction (TRF) and curcumin as anti-cancer agents were examined on both cell lines, respectively.

\section{Methods}

\section{Chemicals and Reagents}

Octanoic acid $\left(\mathrm{C}_{8}\right)$, decanoic acid $\left(\mathrm{C}_{10}\right)$, dodecanoic acid $\left(\mathrm{C}_{12}\right)$, tetradecanoic acid $\left(\mathrm{C}_{14}\right), \mathrm{C}_{16}$ and $\mathrm{C}_{18}$ were provided by Wilmar Pasir Gudang Edible Oils Sdn. Bhd. (Johor, Malaysia). TRF containing 22.8\% $\alpha$-tocopherol, 25.1\% $\alpha$ tocotrienol, $2.7 \% \beta$-tocotrienol, $36.8 \% \gamma$-tocotrienol and $12.5 \% \delta$-tocotrienol was obtained from Supervitamins Sdn. Bhd., (Johor, Malaysia). Curcumin ( $\geq 94 \%$ curcuminoid and $\geq 80 \%$ curcumin), $\mathrm{TA}_{m}$ and $\mathrm{TAC}_{m}$ where $m=12,14,16$ and 18 , sodium bicarbonate, dimethyl sulfoxide, fetal bovine serum and high glucose Dulbecco's modified Eagle medium containing $4500 \mathrm{mg} \mathrm{L}^{-1}$ glucose and $584 \mathrm{mg} \mathrm{L}^{-1}$ L-glutamine were purchased from Sigma-Aldrich (Missouri, USA). Recombinant trypsin (TrypLE ${ }^{\mathrm{TM}}$ Express Enzyme) and penicillin-streptomycin solution containing 10,000 units $\mathrm{mL}^{-1}$ of penicillin and $10,000 \mu \mathrm{g} \mathrm{mL}^{-1}$ of streptomycin were purchased 
from Gibco (New York, USA). Phosphate buffered saline tablets was purchased from Oxoid (Hampshire, UK) while 3-(4,5-dimethylthiazol-2-yl)-2,5diphenyltetrazolium bromide (MTT) was obtained from Invitrogen (New York, USA). All chemicals used in this study were of analytical grade unless stated otherwise.

\section{Preparation of Catanionic Surfactants}

Neat catanionic systems were prepared by using a modified version of a

previously published procedure ${ }^{27}$. In brief, an equimolar ratio of cationic surfactant $\left(\mathrm{TA}_{m}\right.$ and $\mathrm{TAC}_{m}$, where $m=12,14,16$ and 18) and anionic surfactant $\left(\mathrm{C}_{n}\right.$, where $n=$ $8,10,12,14,16$ and 18) were weighed and dissolved together in chloroform. The mixture was allowed to undergo complexation and then isolated as a solid white precipitate by fully evaporated off the chloroform. In the preparation of catanionic stock solution, neat catanionic surfactant was weighed and added into volumetric flask with distilled water, respectively. The catanionic stock solution was kept in water bath with magnetic stirrer at temperature below $55^{\circ} \mathrm{C}$ to ensure neat catanionic surfactant was fully dissolved. The surfactants were sterilized by filtration using 0.2 $\mu \mathrm{M}$ pore size cellulose acetate syringe filters prior to use.

\section{Cell Lines and Cell Culture}

The mouse embryo fibroblast cell line 3T3 was obtained from cell bank of International Medical University (Kuala Lumpur, Malaysia) while human breast cancer cell line MDA-MB-231 (ATCC. HTB-26) was purchased from the American Type Culture Collection (Virginia, USA). Both cell lines were maintained in high 
glucose Dulbecco's modified Eagle medium, supplemented with $3700 \mathrm{mg} \mathrm{mL}^{-1}$ sodium bicarbonate, $10 \%$ of heat-inactivated fetal bovine serum and $1 \%$ of penicillin-streptomycin solution. Cells were cultured in $25 \mathrm{~cm}^{2}$ cell flask in a humidified atmosphere containing $5 \%$ of carbon dioxide at $37^{\circ} \mathrm{C}$.

\section{Cell Seeding and Treatment}

A $100 \mu \mathrm{L}$ of medium containing $1 \times 10^{4}$ cells was seeded into each well of 96-well microplate and incubated for 24 hours prior to treatment. On the following day, both cell lines were treated with seven different concentrations of individual parent surfactants, catanionic surfactants, anti-cancer agents (TRF and curcumin) and mixtures of selected catanionic surfactant with anti-cancer agent. Catanionic surfactants were synthesized and prepared as mentioned above. $2 \mathrm{mM}$ of $\mathrm{TA}_{m}, \mathrm{TAC}_{m}$ and catanionic surfactants were prepared from stock solutions and then further diluted to achieve final concentrations $0 \mu \mathrm{M}$ to $100 \mu \mathrm{M}$ with fresh media. Due to limited solubility of anionic surfactants, TRF and curcumin, they were freshly dissolved in ethanol prior to use. Stock solutions were prepared at concentration of $100 \mathrm{mM}$ for $\mathrm{C}_{n}, 25 \mathrm{mg} \mathrm{mL}^{-1}$ for TRF and curcumin. $\mathrm{C}_{n}$ where $n=8,10,12,14,16$ and 18 were further diluted with fresh media into final concentration of $0 \mu \mathrm{M}$ to 500 $\mu \mathrm{M}$ while TRF and curcumin were at final concentration of $125 \mu \mathrm{g} \mathrm{mL}^{-1}$, respectively. The final concentration of ethanol in the culture medium was always never exceeded $0.5 \%$. Highest concentration of $0.5 \%$ ethanol in working solutions have been proven not toxic to the cells previously ${ }^{28}$. Catanionic surfactant with the highest potential anti-cancer activities among the catanionic surfactants systems was selected for combination with TRF and curcumin, respectively. Based on MTT assay, $\mathrm{C}_{18} \mathrm{TA}_{18}$ was selected and different weight ratios of TRF: $\mathrm{C}_{18} \mathrm{TA}_{18}(1: 1,1: 3,1: 5,1: 10$, 
1:20 and 1:30) and curcumin: $\mathrm{C}_{18} \mathrm{TA}_{18}(1: 5,1: 10.1: 20$ and 1:30) were prepared in according to their solubility limitation. The desired amount of TRF: $\mathrm{C}_{18} \mathrm{TA}_{18}$ and curcumin: $\mathrm{C}_{18} \mathrm{TA}_{18}$ mixtures at respective ratios were weighted and dissolved in aqueous solution at $2 \mathrm{mM}$, followed by sonication at room temperature for 1 hour. The stock solutions were further diluted with fresh media to achieve final concentrations of $0 \mu \mathrm{M}$ to $100 \mu \mathrm{M}$. After subjected to different treatments as described above, the treated cells were incubated for 24 hours post-treatment. Each assay and concentration were tested in triplicate $(n=3)$. Control cells were exposed to culture medium only. The cell density after 24 hours post-treatment was observed using Zeiss Primovert inverted light microscope (Jena, Germany).

\section{MTT Cytotoxicity Assay}

The cytotoxicity of individual parent surfactants, catanionic surfactants, $\mathrm{TRF}$, curcumin, different weight ratios of $\mathrm{C}_{18} \mathrm{TA}_{18}$ :anti-cancer agent (namely, TRF and curcumin) towards MDA-MB-231 and 3T3 cell lines were determined via MTT assay as described by Mosmann ${ }^{29}$. The cell viability of treatment cells was compared relatively to untreated control cells. After 24 hours of post-treatment, a 20 $\mu \mathrm{L}$ of $5 \mathrm{mg} \mathrm{mL}^{-1}$ MTT reagent was added into each well and then the cells were further incubated for 3 hours in humidified atmosphere with 5\% of carbon dioxide at $37^{\circ} \mathrm{C}$. Subsequently, $100 \mu \mathrm{L}$ of dimethyl sulfoxide was added into each well to completely dissolve the formazan crystals. The absorbance was read at $570 \mathrm{~nm}$ using Synergy H1 Hybrid Multi-Mode Reader (Vermont, USA). The results of cytotoxicity assay were expressed as half maximal inhibitory concentration $\left(\mathrm{IC}_{50}\right)$, calculated by fitting experimental data into a dose-response curve. The results were calculated as the percentage of cell viability in relative to untreated cells as control with $100 \%$ 
viability. The percentage of cell viability was calculated according to the following formula:

Percentage of cell viability $=\frac{\text { Absorbance of treated cells at } 570 \mathrm{~nm}}{\text { Absorbance of untreated cells at } 570 \mathrm{~nm}} \times 100$ Equation (1)

\section{Combination Index Analysis}

Combination Index of TRF: $\mathrm{C}_{18} \mathrm{TA}_{18}$ and curcumin: $\mathrm{C}_{18} \mathrm{TA}_{18}$ was calculated using the method described in previous studies ${ }^{30,31}$. A combination index of more than, equal or less than 1 were defined as antagonistic, additive and synergistic effect, respectively ${ }^{30,32}$. The combination index was calculated according to the following formula:

$$
\text { Combination Index }=\frac{C_{A, 50}}{I C_{50, A}}+\frac{C_{B, 50}}{I C_{50, B}}
$$

Where, $C_{A, 50}$ and $C_{B, 50}$ are the concentration required for $\mathrm{C}_{18} \mathrm{TA}_{18}$ and anti-cancer agent (TRF or curcumin) combination to achieve $\mathrm{IC}_{50}$. $\mathrm{IC}_{50, \mathrm{~A}}$ and $\mathrm{IC}_{50, \mathrm{~B}}$ are the $\mathrm{IC}_{50}$ for single compound to achieve the same effect.

\section{Statistical Analysis}

All experiments were performed in triplicates and the results were expressed as means \pm standard deviation. The one-way Analysis of Variance was used to determine the statistical significance difference. Tukey's and Bonferroni's Multiple Comparison Test was conducted subsequently for significant main effects. The GraphPad Prism Version 7.04 software was used for statistical analyses. All results were considered to be statistically significant at $p<0.05$.

\section{Data Availability}

All data generated and analysed during this study are included in this article. 


\section{Results and Discussion}

\section{Cytotoxicity of Parent Surfactants}

Tables 1 and 2 show the in vitro response of 3T3 and MDA-MB-231 cell lines after treated with different alkyl chain length and counterions parent surfactants $\left(\mathrm{TA}_{m}, \mathrm{TAC}_{m}\right.$ and $\left.\mathrm{C}_{n}\right)$ at various concentrations for 24 hours. $3 \mathrm{~T} 3$ cell line was used as a reference for normal cell line when comparing with cancerous MDA-MB-231 cell line. Overall, cytotoxicity response of both cell lines toward all individual parent surfactants happened in a dose-dependent manner. Regardless of the counterions of parent surfactants, cytotoxicity on both cell line increased with the alkyl chain length of cationic and anionic parent surfactants. Increased cytotoxicity with the alkyl chain length of surfactant have been generally related to higher interactions between surfactant and plasma membrane of cells due to higher hydrophobicity in surfactants, that eventually damaged the cells ${ }^{33-35}$.

The percentage of cell viability on both cell lines for quaternary ammonium cationic parent surfactants declined drastically from $0 \mu \mathrm{M}$ to $100 \mu \mathrm{M}$. However, both cell lines remained more than $50 \%$ of cell viability at the concentration of $100 \mu \mathrm{M}$ for $\mathrm{C}_{n}$ anionic parent surfactants where $n=8,10,12,14,16$ and 18 . This result indicates higher cytotoxicity of quaternary ammonium cationic surfactants compared with carboxylic anionic surfactants. Similar outcomes have been reported where cytotoxicity of anionic surfactants was lower than cationic surfactants ${ }^{36,37}$. Moreover, it also had been reported that cationic surfactants was capable to induce apoptosis at a concentration lower than critical micelle concentration via mitochondrial 
dysfunction but anionic or zwitterionic surfactants were less likely to trigger $\operatorname{apoptosis}^{38}$.

Within two different types of quaternary ammonium cationic parent surfactants, $\mathrm{TA}_{m}$ with bromide counterion displayed a higher cytotoxicity to both cell lines than $\mathrm{TAC}_{m}$ with chloride counterion. Higher cytotoxicity of $\mathrm{TA}_{m}$ resulted a steeper declination in the percentage of cell viability versus concentration curve and lower $\mathrm{IC}_{50}$ than $\mathrm{TAC}_{m}$. $\mathrm{IC}_{50}$ of $\mathrm{TA}_{18}$ on both cell lines were significantly lower compared with $\mathrm{TA}_{12}$ and $\mathrm{TA}_{14}$ but not $\mathrm{TA}_{16}$. Besides that, $\mathrm{TAC}_{18}$ also gave significantly lower $\mathrm{IC}_{50}$ in comparison with other alkyl chain length on $3 \mathrm{~T} 3$ and MDA-MB-231 cell lines, except TAC $_{16}$ on MDA-MB-231 cell line. Yet, $\mathrm{IC}_{50}$ of both $\mathrm{TA}_{m}$ and $\mathrm{TAC}_{m}$ on $3 \mathrm{~T} 3$ cell lines still relatively higher than that of MDA-MB-231 cell line. The result was in line with previous study in which cationic surfactants having bromide as a counterion was known to have higher cytotoxicity than the one with chloride counterion ${ }^{34}$.

There was no obvious decline of cell viability when treated with lower alkyl chain length anionic parent surfactants, $\mathrm{C}_{n}$. Among anionic parent surfactants, only $\mathrm{C}_{16}$ and $\mathrm{C}_{18}$ achieved $\mathrm{IC}_{50}$ within the treatment concentration. In agreement with a previous study that demonstrated saturated carboxylic acids with less than fourteen carbon chain length did not inhibit cell proliferation or induce cytotoxicity ${ }^{35} \cdot \mathrm{C}_{18}$ with $\mathrm{IC}_{50}$ of $243.16 \mu \mathrm{M} \pm 1.48 \mu \mathrm{M}$ showed significantly higher cytotoxicity than $\mathrm{C}_{16}$ that gave $\mathrm{IC}_{50}$ of $419.59 \mu \mathrm{M} \pm 3.01 \mu \mathrm{M}$ on $3 \mathrm{~T} 3$ cell line. $\mathrm{IC}_{50}$ of $\mathrm{C}_{16}$ was around twofold of that in $\mathrm{C}_{18}$ treatment on both cell line. Interestingly, both $\mathrm{C}_{16}$ and $\mathrm{C}_{18}$ showed approximately two times lower cytotoxicity on 3T3 cell line compared with MDA- 
MB-231 cell line. Thus, long chain saturated carboxylic acids particularly $\mathrm{C}_{16}$ and $\mathrm{C}_{18}$ effectively inhibited the growth of MDA-MB-231 cell line, provided anti-cancer activities. This was in agreement with previous studies stating $\mathrm{C}_{16}$ and $\mathrm{C}_{18}$ posed anti-cancer activities and induced apoptosis in cancer cells ${ }^{19-21}$. Carboxylic acids were reported to induce apoptosis via disruption of cell membrane integrity, induced DNA fragmentation as well as decreased mitochondrial membrane potential ${ }^{35,39}$.

After 24 hours treatment, the cell density of 3T3 and MDA-MB-231 cell line were observed where at the same parent surfactants treatment concentration, 3T3 cell line showed higher cell density than MDA-MB-231 cell line. The cell density after treated with $\mathrm{TA}_{m}$ was lower than that of $\mathrm{TAC}_{m}$ at the same concentration. Even at $125 \mu \mathrm{M}$ of $\mathrm{C}_{n}$, the cell density observed was still higher than both cell lines treated with $6.25 \mu \mathrm{M}$ of cationic parent surfactants. Since cytotoxicity increased with the alkyl chain length of parent surfactants, the cell density appeared to reduce as the alkyl chain length of parent surfactants increased.

\section{Cytotoxicity of Catanionic Surfactants}

In many instants, improved physicochemical properties are often observed in catanionic surfactants over the single pure form surfactant. Both cell lines achieved $\mathrm{IC}_{50}$ within treatment concentrations, $\mathrm{IC}_{50}$ of each catanionic surfactant on 3T3 and MDA-MB-231 cell line are observed as indicated in Tables 3 and 4. The findings showed cytotoxicity of catanionic surfactants on both cell lines also happened in a dose-dependent manner, this was in line with cytotoxicity pattern of catanionic vesicles on macrophage-like cells ${ }^{7}$ and drug-participating catanionic aggregates on cancer cell lines ${ }^{3}$. 
The cytotoxicity of parent surfactants was clearly reflected in their resulting catanionic surfactants where catanionic surfactant with bromide counterions and higher alkyl chain length displayed higher cytotoxicity on 3T3 and MDA-MB-231 cell lines. In other words, higher alkyl chain length catanionic surfactants with increased hydrophobicity were able to inhibit the cell proliferation more effectively than the lower alkyl chain length combinations. The $\mathrm{IC}_{50}$ of catanionic surfactants on both cell lines were more affected by the change of alkyl chain length in cationic parent surfactants $\left(\mathrm{TA}_{m}\right.$ and $\left.\mathrm{TAC}_{m}\right)$ compared with anionic parent surfactants, $\mathrm{C}_{n}$. This could be related with presence of ammonium group in $\mathrm{TA}_{m}$ and $\mathrm{TAC}_{m}{ }^{40}$. Furthermore, $\mathrm{IC}_{50}$ of catanionic surfactants seems to occur mainly above their respective critical aggregation concentration. This showed that the surfactant aggregates played a crucial role in cytotoxicity ${ }^{41}$.

Enhanced effect of catanionic surfactants over their anionic parent surfactants can be easily seen from their $\mathrm{IC}_{50}$, where substantially lower concentration of catanionic surfactants was needed to inhibit the cell proliferation by the same amount. In comparison with cationic parent surfactants, only some of the catanionic surfactants showed enhanced cytotoxicity, particularly for catanionic surfactants with higher alkyl chain length. Even though $\mathrm{C}_{n} \mathrm{TA}_{m}$ series exhibited higher cytotoxicity than $\mathrm{C}_{n} \mathrm{TAC}_{m}$ series, both of these series were still had lower cytotoxicity on $3 \mathrm{~T} 3$ cell line than MDA-MB-231 cell line. The $\mathrm{IC}_{50}$ of catanionic surfactants on $3 \mathrm{~T} 3$ cell line was $6 \%$ to $77 \%$ higher than MDA-MB-231 cell line for each corresponding $\mathrm{C}_{n} \mathrm{TA}_{m}$, but only higher than MDA-MB-231 cell line by a magnitude of $0.4 \%$ to $39 \%$ for each corresponding $\mathrm{C}_{n} \mathrm{TAC}_{m}$. The overall differences 
in $\mathrm{IC}_{50}$ between both cell lines for $\mathrm{C}_{n} \mathrm{TAC}_{m}$ series were still smaller than that in $\mathrm{C}_{n} \mathrm{TA}_{m}$ series.

$\mathrm{IC}_{50}$ of all four different alkyl chain length catanionic surfactants comprised of the same anionic parent surfactants were found to have difference statistically on $3 \mathrm{~T} 3$ cell line except between $\mathrm{C}_{n} \mathrm{TA}_{16}$ and $\mathrm{C}_{n} \mathrm{TA}_{18}$ as well as between $\mathrm{C}_{18} \mathrm{TAC}_{16}$ and $\mathrm{C}_{18} \mathrm{TAC}_{18}$. When the catanionic surfactants comprised of the same anionic surfactants were compared on MDA-MB-231 cell line, $\mathrm{IC}_{50}$ of $\mathrm{C}_{n} \mathrm{TA}_{12}, \mathrm{C}_{n} \mathrm{TA}_{14}$, $\mathrm{C}_{n} \mathrm{TAC}_{12}$ and $\mathrm{C}_{n} \mathrm{TAC}_{14}$ were significantly higher across the groups, respectively. In contrary, no statistical differences were observed in $\mathrm{IC}_{50}$ of $\mathrm{C}_{n} \mathrm{TA}_{16}$ and $\mathrm{C}_{n} \mathrm{TA}_{18}$ as well as $\mathrm{C}_{n} \mathrm{TAC}_{16}$ and $\mathrm{C}_{n} \mathrm{TAC}_{18}$ on MDA-MB-231 cell line across the group for each corresponding anionic parent surfactants series except for $\mathrm{C}_{18} \mathrm{TA}_{18} \cdot \mathrm{C}_{18} \mathrm{TA}_{m}$ series was the only series that exhibited $\mathrm{IC}_{50}$ which significantly different across all different alkyl chain length cationic parent surfactants on MDA-MB-231 cell line. $\mathrm{C}_{18} \mathrm{TA}_{18}$ showed significantly lower $\mathrm{IC}_{50}$ of $4.04 \mu \mathrm{M} \pm 0.06 \mu \mathrm{M}$ on MDA-MB-231 cell line across the same anionic surfactant homologous group with $\mathrm{IC}_{50}$ of $21.06 \mu \mathrm{M}$ $\pm 0.30 \mu \mathrm{M}, 5.17 \mu \mathrm{M} \pm 0.17 \mu \mathrm{M}$ and $4.61 \mu \mathrm{M} \pm 0.11 \mu \mathrm{M}$ for $\mathrm{C}_{18} \mathrm{TA}_{12}, \mathrm{C}_{18} \mathrm{TA}_{14}$ and $\mathrm{C}_{18} \mathrm{TA}_{16}$, respectively.

From the above, $\mathrm{C}_{18} \mathrm{TA}_{16}$ and $\mathrm{C}_{18} \mathrm{TA}_{18}$ were discovered to have the strongest anti-cancer activities as the lowest concentration was required to inhibit the cell proliferation of MDA-MB-231 cell line. In Figure 1, $\mathrm{C}_{8} \mathrm{TA}_{16}, \mathrm{C}_{10} \mathrm{TA}_{16}, \mathrm{C}_{8} \mathrm{TA}_{18}$ and $\mathrm{C}_{10} \mathrm{TA}_{18}$ promote the cell proliferation of MDA-MB-231 cell line significantly compared with their cationic parent surfactants, rather than cell inhibition. $\mathrm{IC}_{50}$ of $\mathrm{C}_{18} \mathrm{TA}_{16}$ and $\mathrm{C}_{18} \mathrm{TA}_{18}$ on MDA-MB-231 cell line were significantly lower than their 
corresponding cationic parent surfactants. In comparison with $3 \mathrm{~T} 3$ cell line, $\mathrm{C}_{18} \mathrm{TA}_{16}$ and $\mathrm{C}_{18} \mathrm{TA}_{18}$ significantly inhibited cell proliferation on MDA-MB-231 cell line (Figure 2). As mentioned earlier, $\mathrm{C}_{18} \mathrm{TA}_{18}$ inhibited MDA-MB-231 cell line to the highest extent. This indicated the potential of $\mathrm{C}_{18} \mathrm{TA}_{18}$ to be used as anti-cancer agent in certain medical and pharmaceutical areas since lower amount was required than traditional surfactant is one of the importance.

\section{Combination Analysis of $\mathrm{C}_{18} \mathrm{TA}_{18}$ With Other Anti-Cancer Agents}

Cytotoxicity of TRF and curcumin as anti-cancer agents are investigated and shown in Table 5. Similar as previous studies, TRF and curcumin effectively inhibited cell proliferation of cancerous cell compared with healthy normal cell ${ }^{16-18}$. From the results, TRF displayed significantly higher cytotoxicity than curcumin on both cell lines. $\mathrm{IC}_{50}$ of TRF on $3 \mathrm{~T} 3$ cell line was $28.39 \mu \mathrm{g} \mathrm{mL}^{-1} \pm 0.89 \mu \mathrm{g} \mathrm{mL}^{-1}$, slightly higher than that of MDA-MB-231 cell line with $\mathrm{IC}_{50}$ of $22.77 \mu \mathrm{g} \mathrm{mL}{ }^{-1} \pm 0.34$ $\mu \mathrm{g} \mathrm{mL}{ }^{-1}$. Treatment with TRF on MDA-MB-231 cell line gave $\mathrm{IC}_{50}$ that was almost twice lower than that in curcumin. Results indicated that TRF was more potent in the inhibition of cancer cell proliferation than curcumin.

In the previous section, $\mathrm{C}_{18} \mathrm{TA}_{18}$ was revealed as the most potent catanionic surfactant on MDA-MB-231 cell line. Thus, $\mathrm{C}_{18} \mathrm{TA}_{18}$ was selected to be incorporated with TRF and curcumin for combination cytotoxicity evaluation, respectively. Cytotoxicity of different weight ratios of TRF: $\mathrm{C}_{18} \mathrm{TA}_{18}$ and curcumin: $\mathrm{C}_{18} \mathrm{TA}_{18}$ on $3 \mathrm{~T} 3$ and MDA-MB-231 cell lines is illustrated in Figure 3. TRF: $\mathrm{C}_{18} \mathrm{TA}_{18}$ and curcumin: $\mathrm{C}_{18} \mathrm{TA}_{18}$ at all weight ratios displayed significantly lower cytotoxicity than treatment with $\mathrm{C}_{18} \mathrm{TA}_{18}$ alone in both $3 \mathrm{~T} 3$ and MDA-MB-231 cell lines. $3 \mathrm{~T} 3$ cell line 
did not have remarkable difference in cytotoxicity between different weight ratios of TRF: $\mathrm{C}_{18} \mathrm{TA}_{18}\left(\mathrm{IC}_{50}\right.$ ranging from $25 \mu \mathrm{M}$ to $\left.23 \mu \mathrm{M}\right)$, except $1: 1$ weight ratio $\left(\mathrm{IC}_{50}=\right.$ $27.01 \mu \mathrm{M} \pm 0.86 \mu \mathrm{M})$. These $\mathrm{IC}_{50}$ were 3.9-fold to 4.6 -fold higher than that in the treatment with $\mathrm{C}_{18} \mathrm{TA}_{18}$. Yet, $\mathrm{IC}_{50}$ were significantly different between different weight ratios of curcumin: $\mathrm{C}_{18} \mathrm{TA}_{18}$, except between 1:5 and 1:10 weight ratio. In comparison with $\mathrm{C}_{18} \mathrm{TA}_{18}$, the cytotoxicity after incorporating curcumin on $3 \mathrm{~T} 3$ cell line was only 1.8 -fold to 3.5 -fold lower.

For MDA-MB-231 cell line, 1:30 weight ratio of TRF: $\mathrm{C}_{18} \mathrm{TA}_{18}$ and curcumin: $\mathrm{C}_{18} \mathrm{TA}_{18}$ showed the highest cytotoxicity which also exhibited significantly higher cytotoxicity across the experimental weight ratios except 1:20 weight ratio. $\mathrm{IC}_{50}$ of 1:30 TRF: $\mathrm{C}_{18} \mathrm{TA}_{18}$ weight ratio was $4.88 \mu \mathrm{M} \pm 0.28 \mu \mathrm{M}$ and $9.13 \mu \mathrm{M} \pm 0.55$ $\mu \mathrm{M}$ for 1:30 curcumin: $\mathrm{C}_{18} \mathrm{TA}_{18}$ weight ratio on MDA-MB-231 cell line. When higher amount of respective TRF and curcumin was incorporated into $\mathrm{C}_{18} \mathrm{TA}_{18}, \mathrm{IC}_{50}$ of MDA-MB-231 cell line inclined significantly to $10.31 \mu \mathrm{M} \pm 0.20 \mu \mathrm{M}$ at $1: 1$ TRF: $\mathrm{C}_{18} \mathrm{TA}_{18}$ weight ratio and $12.35 \mu \mathrm{M} \pm 0.22 \mu \mathrm{M}$ at 1:5 curcumin: $\mathrm{C}_{18} \mathrm{TA}_{18}$ weight ratio. Even though the cytotoxicity was lower after incorporation of anti-cancer agents, 1:20 and 1:30 TRF: $\mathrm{C}_{18} \mathrm{TA}_{18}$ still showing enhanced cytotoxicity over their parent surfactants on MDA-MB-231 cell line.

As clearly seen in Figure $3 \mathrm{~b}$, incorporation of TRF into $\mathrm{C}_{18} \mathrm{TA}_{18}$ showed much lower $\mathrm{IC}_{50}$ than incorporation of curcumin. This indicated that incorporation of TRF into $\mathrm{C}_{18} \mathrm{TA}_{18}$ resulted more favourable anti-cancer activities than curcumin on MDA-MB-231 cell line. Although cytotoxicity on MDA-MB-231 cell line reduced after incorporation of anti-cancer agents into $\mathrm{C}_{18} \mathrm{TA}_{18}$, the $\mathrm{IC}_{50}$ still showed improved 
anti-cancer activities compared with $\mathrm{IC}_{50}$ of an anti-cancer prodrug-participating catanionic aggregates on leukaemia and breast cancer cell lines in recent study ${ }^{3}$. Noticeably, $\mathrm{IC}_{50}$ of different weight ratios of TRF: $\mathrm{C}_{18} \mathrm{TA}_{18}$ were found to be at least $50 \%$ lower than that on $3 \mathrm{~T} 3$ cell line under the same treatment. Hence, different weight ratios of TRF: $\mathrm{C}_{18} \mathrm{TA}_{18}$ showed potential anti-cancer activities.

The combination index of different weight ratios of TRF: $\mathrm{C}_{18} \mathrm{TA}_{18}$ and curcumin: $\mathrm{C}_{18} \mathrm{TA}_{18}$ was calculated based on Chou and Talalay's Combination Index equation and shown in Table 6. Unfortunately, none of the experimental combinations provide synergistic effects on inhibition of cancer cell proliferation. Therefore, respective incorporation of TRF and curcumin as anti-cancer agents with $\mathrm{C}_{18} \mathrm{TA}_{18}$ did not further enhance the anti-cancer activities on MDA-MB-231 cell line. However, the presence of very minute quantity of TRF and curcumin that had been well-recognized to possess antioxidant properties greatly reduced the cytotoxicity of $\mathrm{C}_{18} \mathrm{TA}_{18}$ on $3 \mathrm{~T} 3$ cell line especially with the incorporation of TRF.

Effects of different weight ratios of TRF: $\mathrm{C}_{18} \mathrm{TA}_{18}$ and curcumin: $\mathrm{C}_{18} \mathrm{TA}_{18}$ in respect to untreated control cells are also revealed in the resulted cell density. At 6.25 $\mu \mathrm{M}$ of different weight ratios of TRF: $\mathrm{C}_{18} \mathrm{TA}_{18}$ and curcumin: $\mathrm{C}_{18} \mathrm{TA}_{18}, 3 \mathrm{~T} 3$ cell line remained with good cell confluency under inverted microscope. Conversely, the cell viability of MDA-MB-231 cell line was relatively low where low cell density was observed at $6.25 \mu \mathrm{M}$ of TRF: $\mathrm{C}_{18} \mathrm{TA}_{18}$ and curcumin: $\mathrm{C}_{18} \mathrm{TA}_{18}$ weight ratio. Besides that, incorporation of TRF into $\mathrm{C}_{18} \mathrm{TA}_{18}$ resulted lower cell density than that of curcumin at the same treatment ratio. Therefore, TRF was more suitable to be 
incorporated with $\mathrm{C}_{18} \mathrm{TA}_{18}$ in order to kill the cancer cells at greatest magnitude but with minimal damage on healthy cells.

\section{Conclusion}

The present study suggests catanionic surfactant is able to inhibit the proliferation of cancerous MDA-MB-231 cell line more effectively than all their anionic parent surfactants and some of their cationic parent surfactants. Among all catanionic surfactants, $\mathrm{C}_{18} \mathrm{TA}_{18}$ had significantly inhibited the proliferation of MDA-MB-231 cell line to the highest extend. Respective incorporation of TRF and curcumin into $\mathrm{C}_{18} \mathrm{TA}_{18}$ did not further improve the in vitro cytotoxicity on MDA-MB-231 cell line. Yet, the cytotoxicity of $\mathrm{C}_{18} \mathrm{TA}_{18}$ on $3 \mathrm{~T} 3$ cell line was significantly reduced after incorporation of TRF and curcumin into $\mathrm{C}_{18} \mathrm{TA}_{18}$, respectively. This shows the potential of $\mathrm{C}_{18} \mathrm{TA}_{18}$ to be used as an anti-cancer agent in its pristine form as well as with other anti-cancer agents. 


\section{References}

1 Tadros, T. Encyclopedia of Colloid and Interface Science. (Springer Berlin Heidelberg, 2013).

2 Jokela, P., Joensson, B. \& Khan, A. Phase equilibria of catanionic surfactantwater systems. The Journal of Physical Chemistry 91, 3291-3298, doi:10.1021/j100296a037 (1987).

3 Jiang, Y., Hu, X., Zhang, J., Jin, G. \& Luan, Y. Chlorambucil prodrugparticipating catanionic aggregates for sustained drug release and improved antitumour activity. Journal of Molecular Liquids 274, 556-561, doi:https://doi.org/10.1016/j.molliq.2018.10.165 (2019).

4 Dubois, M. et al. Self-assembly of regular hollow icosahedra in salt-free catanionic solutions. Nature 411, 672-675, doi:10.1038/35079541 (2001).

5 Hao, J. \& Hoffmann, H. Self-assembled structures in excess and salt-free catanionic surfactant solutions. Current Opinion in Colloid and Interface Science 9, 279-293, doi:https://doi.org/10.1016/j.cocis.2004.06.004 (2004).

6 Dhawan, V. V. \& Nagarsenker, M. S. Catanionic systems in nanotherapeutics - Biophysical aspects and novel trends in drug delivery applications. Journal of Controlled Release 266, 331-345, doi:https://doi.org/10.1016/j.jconrel.2017.09.040 (2017).

7 Kuo, J.-H. S., Jan, M.-S., Chang, C.-H., Chiu, H.-W. \& Li, C.-T. Cytotoxicity characterization of catanionic vesicles in RAW 264.7 murine macrophagelike cells. Colloids and Surfaces B: Biointerfaces 41, 189-196, doi:http://dx.doi.org/10.1016/j.colsurfb.2004.12.008 (2005).

8 Aiello, C., Andreozzi, P., La Mesa, C. \& Risuleo, G. Biological activity of SDS-CTAB cat-anionic vesicles in cultured cells and assessment of their cytotoxicity ending in apoptosis. Colloids and Surfaces B: Biointerfaces 78, 149-154, doi:https://doi.org/10.1016/j.colsurfb.2010.02.013 (2010).

9 Kuo, Y.-C. \& Hong, T.-Y. Delivering etoposide to the brain using catanionic solid lipid nanoparticles with surface 5-HT-moduline. International Journal of Pharmaceutics 465, 132-142, doi:https://doi.org/10.1016/j.ijpharm.2014.02.008 (2014).

10 Kuo, Y.-C. \& Wang, C.-C. Carmustine-loaded catanionic solid lipid nanoparticles with serotonergic $1 \mathrm{~B}$ receptor subtype antagonist for in vitro targeted delivery to inhibit brain cancer growth. Journal of the Taiwan Institute of Chemical Engineers 46, 1-14, doi:https://doi.org/10.1016/j.jtice.2014.08.035 (2015).

$11 \mathrm{Li}, \mathrm{S}$. et al. Catanionic lipid nanosystems improve pharmacokinetics and antilung cancer activity of curcumin. Nanomedicine: Nanotechnology, Biology and Medicine 12, 1567-1579, doi:https://doi.org/10.1016/j.nano.2016.02.007 (2016).

12 Rivera-Franco, M. M. \& Leon-Rodriguez, E. Delays in Breast Cancer Detection and Treatment in Developing Countries. Breast Cancer: Basic and Clinical Research 12, 1178223417752677 , doi:10.1177/1178223417752677 (2018).

13 Brouckaert, O., Wildiers, H., Floris, G. \& Neven, P. Update on triplenegative breast cancer: prognosis and management strategies. International Journal of Women's Health 4, 511-520, doi:10.2147/IJWH.S18541 (2012).

14 Mehanna, J., Haddad, F. G., Eid, R., Lambertini, M. \& Kourie, H. R. Triplenegative breast cancer: current perspective on the evolving therapeutic 
landscape. International Journal of Women's Health 11, 431-437, doi:10.2147/IJWH.S178349 (2019).

15 Singh, K., Bhori, M., Kasu, Y. A., Bhat, G. \& Marar, T. Antioxidants as precision weapons in war against cancer chemotherapy induced toxicity Exploring the armoury of obscurity. Saudi Pharmaceutical Journal 26, 177190, doi:10.1016/j.jsps.2017.12.013 (2018).

16 Comitato, R., Ambra, R. \& Virgili, F. Tocotrienols: A Family of Molecules with Specific Biological Activities. Antioxidants 6, doi:10.3390/antiox6040093 (2017).

17 Nesaretnam, K., Meganathan, P., Veerasenan, S. D. \& Selvaduray, K. R. Tocotrienols and breast cancer: the evidence to date. Genes and Nutrition 7 , 3-9, doi:10.1007/s12263-011-0224-z (2012).

18 Wilken, R., Veena, M. S., Wang, M. B. \& Srivatsan, E. S. Curcumin: A review of anti-cancer properties and therapeutic activity in head and neck squamous cell carcinoma. Molecular cancer 10, 12, doi:10.1186/1476-459810-12 (2011).

19 Hardy, S. et al. Saturated Fatty Acid-induced Apoptosis in MDA-MB-231 Breast Cancer Cells: A ROLE FOR CARDIOLIPIN. Journal of Biological Chemistry 278, 31861-31870, doi:10.1074/jbc.M300190200 (2003).

20 Evans, L. M., Cowey, S. L., Siegal, G. P. \& Hardy, R. W. Stearate preferentially induces apoptosis in human breast cancer cells. Nutrition and Cancer 61, 746-753, doi:10.1080/01635580902825597 (2009).

21 Khan, A. A., Alanazi, A. M., Jabeen, M., Chauhan, A. \& Abdelhameed, A. S. Design, synthesis and in vitro anticancer evaluation of a stearic acid-based ester conjugate. Anticancer research 33, 2517-2524 (2013).

22 Habib, N. A. et al. Stearic acid and carcinogenesis. British Journal of Cancer 56, 455-458, doi:10.1038/bjc.1987.223 (1987).

23 Fermor, B. F. et al. Fatty acid composition of normal and malignant cells and cytotoxicity of stearic, oleic and sterculic acids in vitro. European Journal of Cancer 28, 1143-1147, doi:https://doi.org/10.1016/0959-8049(92)90475-H (1992).

24 Wickramasinghe, N. S., Jo, H., McDonald, J. M. \& Hardy, R. W. Stearate inhibition of breast cancer cell proliferation. A mechanism involving epidermal growth factor receptor and G-proteins. The American journal of pathology 148, 987-995 (1996).

25 Singh, R. K. et al. Stearate inhibits human tumor cell invasion. Invasion \& metastasis 15, 144-155 (1995).

26 Jiang, Y., Luan, Y., Qin, F., Zhao, L. \& Li, Z. Catanionic vesicles from an amphiphilic prodrug molecule: a new concept for drug delivery systems. RSC Advances 2, 6905-6912, doi:10.1039/C2RA20653F (2012).

27 Gavrilko, T. et al. FTIR and DSC Studies of Binary Mixtures of Long-Chain Aliphatic Compounds: Lauric Acid-Cetyl-trimethylammonium Bromide. Ukrainian Journal of Physics 63, 413-424 (2018).

28 Siddiqui, R. A. et al. Docosahexaenoic acid induces apoptosis in Jurkat cells by a protein phosphatase-mediated process. Biochimica et Biophysica Acta (BBA) - Molecular Cell Research 1499, 265-275 (2001).

29 Mosmann, T. Rapid colorimetric assay for cellular growth and survival: application to proliferation and cytotoxicity assays. Journal of immunological methods 65, 55-63 (1983). 
30 Chou, T.-C. Theoretical Basis, Experimental Design, and Computerized Simulation of Synergism and Antagonism in Drug Combination Studies. Pharmacological Reviews 58, 621-681, doi:10.1124/pr.58.3.10 (2006).

31 Aldhirgham, T., Henderson, K., Nigam, P. \& Owusu-Apenten, R. K. A Combination of Curcumin from Turmeric and Alpha-linolenic Acid Shows Antagonism with MCF-7 Breast Cancer Cells in Phenol-red Free Medium. Journal of Applied Life Sciences International 10, 1-12 (2016).

32 Chou, T.-C. The combination index (CI < 1) as the definition of synergism and of synergy claims. Synergy 7, 49-50, doi:https://doi.org/10.1016/j.synres.2018.04.001 (2018).

33 Zhang, S. et al. Antibacterial Activity, in Vitro Cytotoxicity, and Cell Cycle Arrest of Gemini Quaternary Ammonium Surfactants. Langmuir 31, 1216112169, doi:10.1021/acs.langmuir.5b01430 (2015).

34 Inacio, A. S. et al. In vitro surfactant structure-toxicity relationships: implications for surfactant use in sexually transmitted infection prophylaxis and contraception. PLoS One 6, e19850, doi:10.1371/journal.pone.0019850 (2011).

35 Harvey, K. A. et al. Long-chain saturated fatty acids induce proinflammatory responses and impact endothelial cell growth. Clinical Nutrition 29, 492-500, doi:10.1016/j.clnu.2009.10.008 (2010).

36 Vlachy, N., Touraud, D., Heilmann, J. \& Kunz, W. Determining the cytotoxicity of catanionic surfactant mixtures on HeLa cells. Colloids and Surfaces B: Biointerfaces 70, 278-280, doi:https://doi.org/10.1016/j.colsurfb.2008.12.038 (2009).

37 Sanchez, L., Mitjans, M., Infante, M. R. \& Vinardell, M. P. Potential irritation of lysine derivative surfactants by hemolysis and $\mathrm{HaCaT}$ cell viability. Toxicology Letters 161, 53-60, doi:https://doi.org/10.1016/j.toxlet.2005.07.015 (2006).

38 Enomoto, R. et al. Cationic Surfactants Induce Apoptosis in Normal and Cancer Cells. Annals of the New York Academy of Sciences 1095, 1-6, doi:10.1196/annals.1397.001 (2007).

39 Martins de Lima, T., Cury-Boaventura, Maria F., Giannocco, G., Nunes, Maria T. \& Curi, R. Comparative toxicity of fatty acids on a macrophage cell line (J774). Clinical Science 111, 307-317, doi:10.1042/cs20060064 (2006).

40 Colomer, A. et al. pH-Sensitive Surfactants from Lysine: Assessment of Their Cytotoxicity and Environmental Behavior. Langmuir 28, 5900-5912, doi:10.1021/la203974f (2012).

41 Egorova, E. M. \& Kaba, S. I. The effect of surfactant micellization on the cytotoxicity of silver nanoparticles stabilized with aerosol-OT. Toxicology in Vitro 57, 244-254, doi:https://doi.org/10.1016/j.tiv.2019.03.006 (2019). 


\section{Acknowledgements}

The authors gratefully acknowledge Malaysian Palm Oil Board for the support of this work.

\section{Author Contributions}

X.S.Y. and W.H.L. designed and developed the synthesis of catanionic surfactants described in this paper. X.S.Y. conducted and analysed the cytotoxicity experiment with the supervising of L.Y.P. and N.B.M.A. W.H.L. and L.Y.P. discussed and provided crucial feedback for all the experimental part. W.H.L., L.Y.P., N.B.M.A. and C.H.C. were responsible for the final content check. All the authors have reviewed the manuscript.

\section{Competing Interest}

The authors declare no competing interests. 
Table 1. $\mathrm{IC}_{50}$ of cationic parent surfactants on $3 \mathrm{~T} 3$ and MDA-MB-231 cell lines

\begin{tabular}{|c|c|c|c|c|}
\hline \multirow{2}{*}{ Cell lines } & \multicolumn{4}{|c|}{ IC $_{50}$ of Cationic Parent Surfactants $(\mu \mathrm{M})$} \\
\hline & $\mathbf{T} \mathbf{A}_{12}$ & $\mathbf{T} \mathbf{A}_{14}$ & $\mathbf{T A}_{16}$ & $\mathbf{T A}_{18}$ \\
\hline $3 T 3$ & $27.75 \pm 1.42^{\mathrm{a}}$ & $14.40 \pm 1.12^{\mathrm{b}}$ & $7.32 \pm 0.28^{\mathrm{c}}$ & $6.50 \pm 0.48^{c}$ \\
\hline \multirow[t]{2}{*}{ MDA-MB-231 } & $22.50 \pm 0.91^{\mathrm{a}}$ & $9.43 \pm 0.46^{\mathrm{b}}$ & $6.38 \pm 0.32^{c}$ & $5.77 \pm 0.25^{\mathrm{c}}$ \\
\hline & $\mathbf{T A C}_{12}$ & TAC $_{14}$ & TAC $_{16}$ & TAC $_{18}$ \\
\hline $3 T 3$ & $56.59 \pm 0.49^{\mathrm{a}}$ & $21.20 \pm 0.92^{b}$ & $14.02 \pm 0.51^{\mathrm{c}}$ & $11.00 \pm 0.21^{\mathrm{d}}$ \\
\hline MDA-MB-231 & $51.11 \pm 2.91^{\mathrm{a}}$ & $18.84 \pm 1.09^{b}$ & $11.69 \pm 0.57^{\mathrm{c}}$ & $9.28 \pm 0.29^{c}$ \\
\hline
\end{tabular}

$*$ Values were means \pm standard deviation $(n=3)$. Values with different letters within the same row were significantly different $(p<0.05)$.

Table 2. $\mathrm{IC}_{50}$ of anionic parent surfactants on $3 \mathrm{~T} 3$ and MDA-MB-231 cell lines

\begin{tabular}{|c|c|c|c|c|c|c|}
\hline \multirow{2}{*}{ Cell lines } & \multicolumn{6}{|c|}{$\mathrm{IC}_{50}$ of Anionic Parent Surfactants $(\boldsymbol{\mu M})$} \\
\hline & $\mathbf{C}_{8}$ & $\mathbf{C}_{10}$ & $\mathbf{C}_{12}$ & $\mathbf{C}_{14}$ & $\mathbf{C}_{16}$ & $\mathbf{C}_{18}$ \\
\hline $3 \mathrm{T3}$ & \multicolumn{4}{|c|}{$>500$} & $419.59 \pm 3.01^{\mathrm{a}}$ & $243.16 \pm 1.48^{b}$ \\
\hline MDA-MB-231 & \multicolumn{4}{|c|}{$>500$} & $231.49 \pm 5.95^{\mathrm{a}}$ & $102.88 \pm 1.21^{\mathrm{b}}$ \\
\hline
\end{tabular}

$*$ Values were means \pm standard deviation $(n=3)$. Values with different letters within the same row were significantly different $(p<0.05)$. 
Table 3. $\mathrm{IC}_{50}$ of catanionic surfactants on $3 \mathrm{~T} 3$ cell line

\begin{tabular}{|c|c|c|c|c|}
\hline \multirow{3}{*}{$\begin{array}{c}\text { Anionic } \\
\text { Surfactant }\end{array}$} & \multicolumn{4}{|c|}{$\mathrm{IC}_{50}$ of Catanionic Surfactants $(\boldsymbol{\mu M})$} \\
\hline & \multicolumn{4}{|c|}{ Cationic Surfactant } \\
\hline & $\mathbf{T} \mathbf{A}_{12}$ & $\mathbf{T A}_{14}$ & $\mathbf{T A}_{16}$ & $\mathbf{T} \mathbf{A}_{18}$ \\
\hline $\mathrm{C}_{8}$ & $43.76 \pm 0.92^{\mathrm{a}}$ & $19.65 \pm 0.72^{b}$ & $10.79 \pm 0.64^{\mathrm{c}}$ & $9.75 \pm 0.27^{\mathrm{c}}$ \\
\hline $\mathbf{C}_{10}$ & $39.60 \pm 0.39^{a}$ & $15.34 \pm 0.56^{\mathrm{b}}$ & $10.20 \pm 0.23^{\mathrm{c}}$ & $9.20 \pm 0.35^{\mathrm{c}}$ \\
\hline $\mathbf{C}_{12}$ & $33.01 \pm 0.99^{\mathrm{a}}$ & $14.45 \pm 0.94^{\mathrm{b}}$ & $9.45 \pm 0.37^{\mathrm{c}}$ & $8.99 \pm 0.30^{c}$ \\
\hline $\mathbf{C}_{14}$ & $29.23 \pm 2.08^{\mathrm{a}}$ & $12.12 \pm 0.43^{b}$ & $8.44 \pm 0.29^{c}$ & $7.05 \pm 0.35^{\mathrm{c}}$ \\
\hline $\mathbf{C}_{16}$ & $28.20 \pm 1.34^{\mathrm{a}}$ & $11.30 \pm 0.20^{\mathrm{b}}$ & $7.54 \pm 0.36^{\mathrm{c}}$ & $6.56 \pm 0.33^{\mathrm{c}}$ \\
\hline \multirow[t]{2}{*}{$\mathrm{C}_{18}$} & $27.14 \pm 1.53^{\mathrm{a}}$ & $10.11 \pm 0.50^{b}$ & $6.11 \pm 0.27^{\mathrm{c}}$ & $5.90 \pm 0.28^{\mathrm{c}}$ \\
\hline & $\mathbf{T A C}_{12}$ & TAC $_{14}$ & TAC $_{16}$ & TAC $_{18}$ \\
\hline $\mathrm{C}_{8}$ & $63.94 \pm 1.36^{\mathrm{a}}$ & $29.90 \pm 0.60^{\mathrm{b}}$ & $17.47 \pm 0.42^{\mathrm{c}}$ & $12.75 \pm 0.52^{\mathrm{d}}$ \\
\hline $\mathbf{C}_{10}$ & $62.03 \pm 0.47^{\mathrm{a}}$ & $26.67 \pm 0.50^{\mathrm{b}}$ & $16.13 \pm 0.22^{\mathrm{c}}$ & $12.29 \pm 0.07^{\mathrm{d}}$ \\
\hline $\mathbf{C}_{12}$ & $61.21 \pm 0.41^{\mathrm{a}}$ & $24.93 \pm 0.93^{b}$ & $15.25 \pm 0.36^{\mathrm{c}}$ & $11.96 \pm 0.18^{\mathrm{d}}$ \\
\hline $\mathbf{C}_{14}$ & $60.08 \pm 0.79^{\mathrm{a}}$ & $19.17 \pm 0.19^{b}$ & $14.25 \pm 0.66^{\mathrm{c}}$ & $11.54 \pm 0.01^{\mathrm{d}}$ \\
\hline $\mathbf{C}_{16}$ & $59.31 \pm 0.98^{a}$ & $18.54 \pm 0.36^{b}$ & $13.61 \pm 0.20^{c}$ & $11.17 \pm 0.19^{d}$ \\
\hline $\mathrm{C}_{18}$ & $58.25 \pm 0.24^{\mathrm{a}}$ & $17.37 \pm 0.27^{\mathrm{b}}$ & $10.70 \pm 0.28^{c}$ & $10.40 \pm 0.17^{\mathrm{c}}$ \\
\hline
\end{tabular}

$*$ Values were means \pm standard deviation $(n=3)$. Values with different letters within the same row were significantly different $(p<0.05)$. 
Table 4. $\mathrm{IC}_{50}$ of catanionic surfactants on MDA-MB-231 cell line

\begin{tabular}{|c|c|c|c|c|}
\hline \multirow{3}{*}{$\begin{array}{c}\text { Anionic } \\
\text { Surfactant }\end{array}$} & \multicolumn{4}{|c|}{$\mathrm{IC}_{50}$ of Catanionic Surfactants $(\boldsymbol{\mu M})$} \\
\hline & \multicolumn{4}{|c|}{ Cationic Surfactant } \\
\hline & $\mathbf{T A}_{12}$ & $\mathbf{T A}_{14}$ & $\mathbf{T A}_{16}$ & $\mathbf{T A}_{18}$ \\
\hline $\mathrm{C}_{8}$ & $29.76 \pm 0.95^{\mathrm{a}}$ & $18.51 \pm 0.29^{b}$ & $8.24 \pm 0.45^{\mathrm{c}}$ & $7.19 \pm 0.25^{\mathrm{c}}$ \\
\hline $\mathbf{C}_{10}$ & $26.90 \pm 0.38^{\mathrm{a}}$ & $10.84 \pm 0.33^{\mathrm{b}}$ & $7.29 \pm 0.16^{\mathrm{c}}$ & $6.69 \pm 0.43^{c}$ \\
\hline $\mathbf{C}_{12}$ & $25.63 \pm 0.12^{\mathrm{a}}$ & $9.61 \pm 0.24^{\mathrm{b}}$ & $6.43 \pm 0.46^{\mathrm{c}}$ & $5.90 \pm 0.35^{\mathrm{c}}$ \\
\hline $\mathrm{C}_{14}$ & $23.91 \pm 0.50^{\mathrm{a}}$ & $9.02 \pm 0.25^{\mathrm{b}}$ & $6.12 \pm 0.33^{\mathrm{c}}$ & $5.43 \pm 0.11^{\mathrm{c}}$ \\
\hline $\mathbf{C}_{16}$ & $23.17 \pm 0.71^{\mathrm{a}}$ & $8.32 \pm 0.47^{\mathrm{b}}$ & $5.65 \pm 0.17^{\mathrm{c}}$ & $5.09 \pm 0.16^{\mathrm{c}}$ \\
\hline \multirow[t]{2}{*}{$\mathrm{C}_{18}$} & $21.06 \pm 0.30^{\mathrm{a}}$ & $5.71 \pm 0.17^{\mathrm{b}}$ & $4.61 \pm 0.11^{\mathrm{c}}$ & $4.04 \pm 0.06^{\mathrm{d}}$ \\
\hline & $\mathbf{T A C}_{12}$ & $\mathbf{T A C}_{14}$ & TAC $_{16}$ & TAC $_{18}$ \\
\hline $\mathrm{C}_{8}$ & $62.50 \pm 0.73^{\mathrm{a}}$ & $21.56 \pm 1.24^{\mathrm{b}}$ & $12.61 \pm 0.75^{\mathrm{c}}$ & $12.38 \pm 0.41^{\mathrm{c}}$ \\
\hline $\mathbf{C}_{10}$ & $60.92 \pm 1.65^{\mathrm{a}}$ & $20.93 \pm 1.27^{b}$ & $12.20 \pm 0.30^{c}$ & $12.03 \pm 0.55^{\mathrm{c}}$ \\
\hline $\mathbf{C}_{12}$ & $59.73 \pm 2.31^{\mathrm{a}}$ & $19.93 \pm 0.71^{\mathrm{b}}$ & $11.73 \pm 0.40^{\mathrm{c}}$ & $11.44 \pm 0.39^{c}$ \\
\hline $\mathrm{C}_{14}$ & $58.62 \pm 1.35^{\mathrm{a}}$ & $19.35 \pm 0.98^{\mathrm{b}}$ & $11.36 \pm 0.60^{\mathrm{c}}$ & $11.11 \pm 0.62^{\mathrm{c}}$ \\
\hline $\mathrm{C}_{16}$ & $57.80 \pm 2.15^{\mathrm{a}}$ & $18.30 \pm 0.34^{\mathrm{b}}$ & $11.04 \pm 0.63^{\mathrm{c}}$ & $10.51 \pm 0.63^{\mathrm{c}}$ \\
\hline $\mathrm{C}_{18}$ & $56.92 \pm 2.14^{\mathrm{a}}$ & $17.30 \pm 0.66^{b}$ & $10.28 \pm 0.48^{c}$ & $9.86 \pm 0.24^{\mathrm{c}}$ \\
\hline
\end{tabular}

$*$ Values were means \pm standard deviation $(\mathrm{n}=3)$. Values with different letters within the same row were significantly different $(p<0.05)$. 
Table 5. $\mathrm{IC}_{50}$ of TRF and curcumin on $3 \mathrm{~T} 3$ and MDA-MB-231 cell line

\begin{tabular}{ccc}
\hline \multirow{2}{*}{ Cell lines } & \multicolumn{2}{c}{ IC $_{\mathbf{5 0}}$ of Anti-Cancer Agents $(\boldsymbol{\mu g} / \mathbf{m L})$} \\
\cline { 2 - 3 } & TRF & Curcumin \\
\hline 3T3 & $28.39 \pm 0.89^{\mathrm{a}}$ & $75.80 \pm 0.51$ \\
MDA-MB-231 & $22.77 \pm 0.34^{\mathrm{a}}$ & $42.70 \pm 1.08$ \\
\hline
\end{tabular}

$*$ Values were means \pm standard deviation $(n=3)$. Values with different letters within the same row were significantly different $(p<0.05)$.

Table 6. Combination Index of different weight ratios of $\mathrm{TRF}: \mathrm{C}_{18} \mathrm{TA}_{18}$ and curcumin: $\mathrm{C}_{18} \mathrm{TA}_{18}$ on $3 \mathrm{~T} 3$ and MDA-MB-231 cell line

\begin{tabular}{|c|c|c|c|c|}
\hline \multirow{3}{*}{$\begin{array}{c}\text { Weight } \\
\text { Ratio }\end{array}$} & \multicolumn{4}{|c|}{ Combination Index } \\
\hline & \multicolumn{2}{|c|}{ TRF } & \multicolumn{2}{|c|}{ Curcumin } \\
\hline & MDA-MB-231 & $3 T 3$ & MDA-MB-231 & $3 \mathrm{~T} 3$ \\
\hline 1:1 & 2.86 & 5.22 & - & - \\
\hline $1: 3$ & 2.45 & 4.43 & - & - \\
\hline $1: 5$ & 2.15 & 4.22 & 3.09 & 3.58 \\
\hline 1:10 & 1.60 & 4.10 & 2.51 & 2.70 \\
\hline $1: 20$ & 1.36 & 3.94 & 2.41 & 2.61 \\
\hline $1: 30$ & 1.21 & 3.93 & 2.26 & 1.79 \\
\hline
\end{tabular}

*The combination index was calculated using Chou and Talalay's Combination Index equation. 


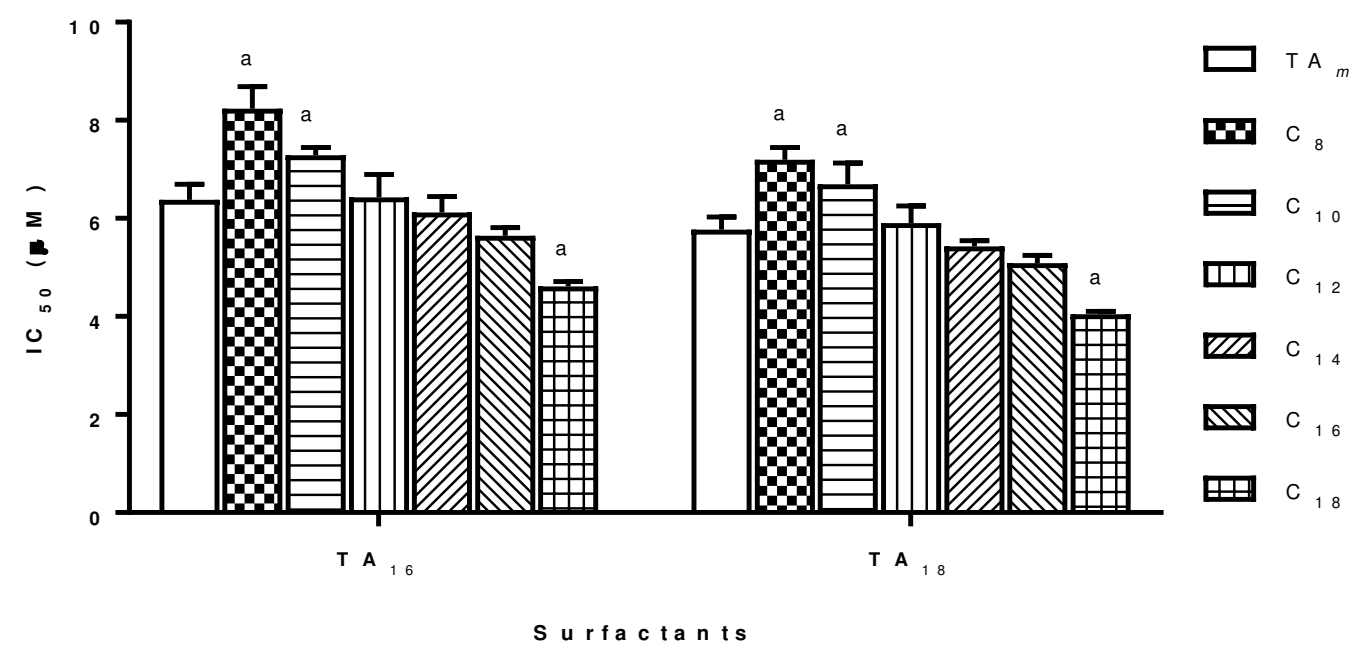

Figure 1. $\mathrm{IC}_{50}$ of $\mathrm{TA}_{16}, \mathrm{TA}_{18}, \mathrm{C}_{n} \mathrm{TA}_{16}$ and $\mathrm{C}_{n} \mathrm{TA}_{18}$ on MDA-MB-231 cell line after 24 hours treatment. The data were expressed as means \pm standard deviation $(n=3)$. Data with different letters within the same group were significantly different $(p<$ 0.05) compared with $\mathrm{TA}_{m}$, respectively.

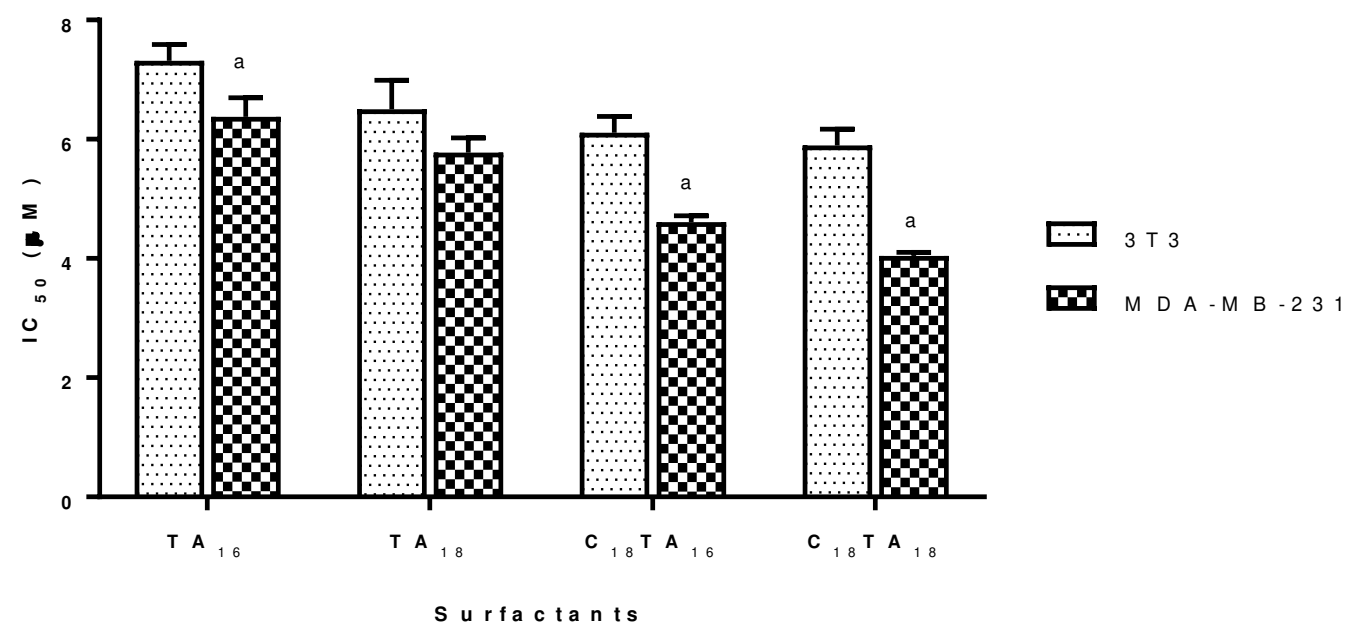

Figure 2. $\mathrm{IC}_{50}$ of $\mathrm{TA}_{16}, \mathrm{TA}_{18}, \mathrm{C}_{18} \mathrm{TA}_{16}$ and $\mathrm{C}_{18} \mathrm{TA}_{18}$ on $3 \mathrm{~T} 3$ and MDA-MB-231 cell lines after 24 hours treatment. The data were expressed as means \pm standard deviation $(\mathrm{n}=3)$. Data with different letters within the same group were significantly different $(p<0.05)$. 
(a)

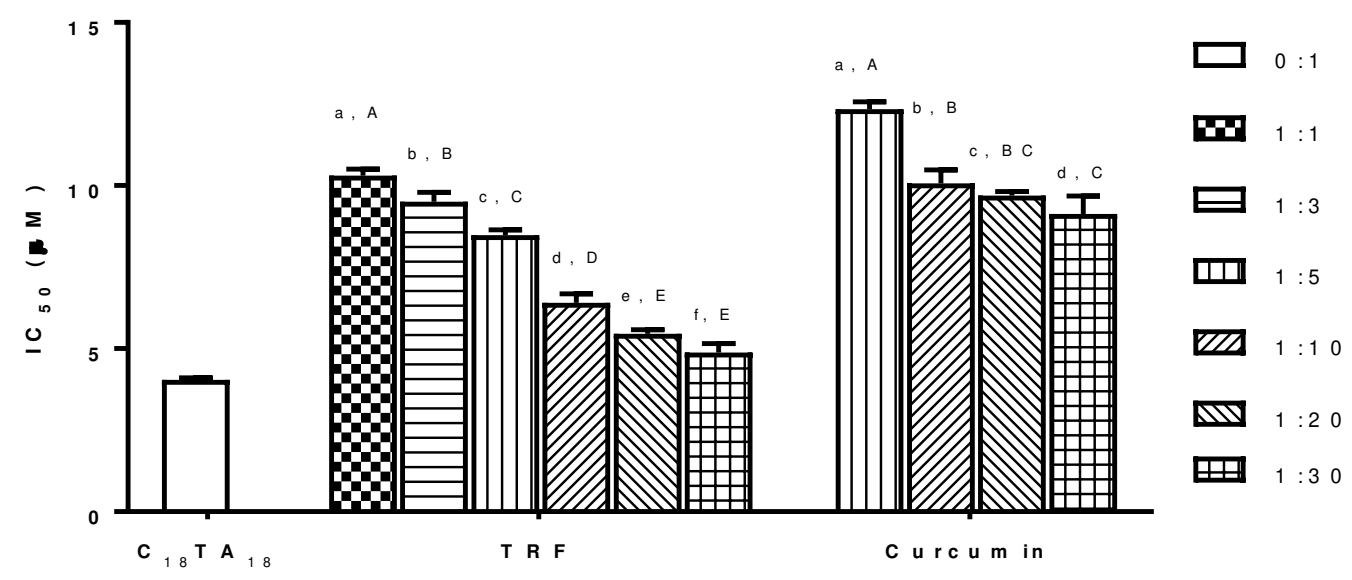

(b)

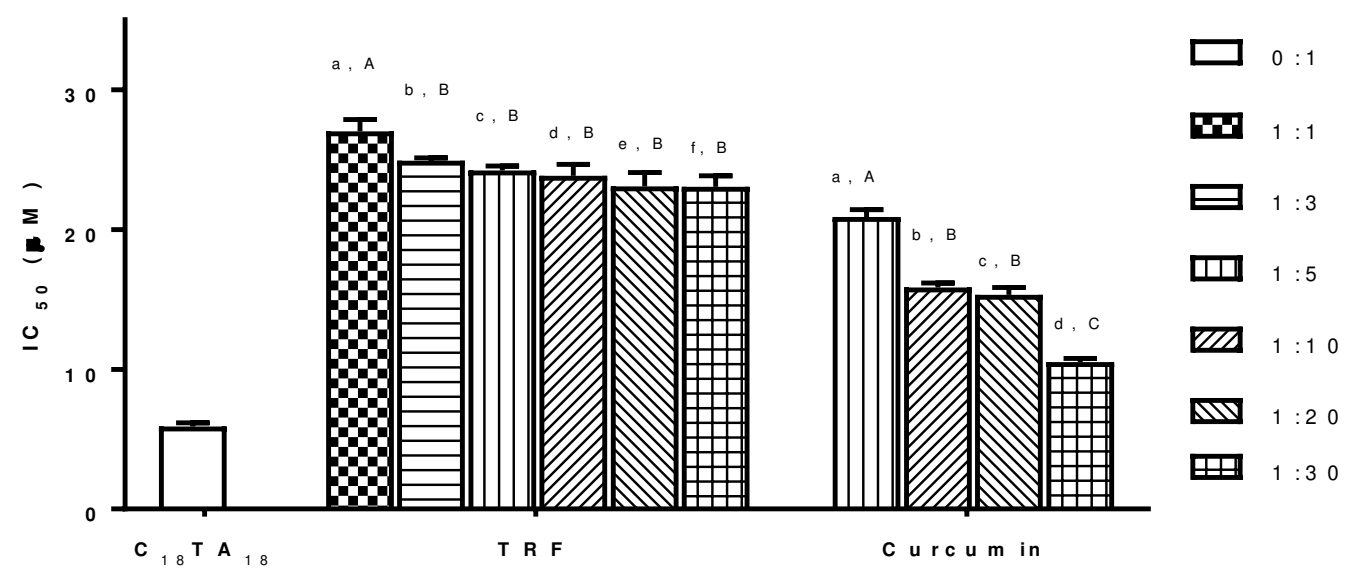

Figure 3. $\mathrm{IC}_{50}$ of $\mathrm{TA}_{18}$, different weight ratios of $\mathrm{TRF}: \mathrm{C}_{18} \mathrm{TA}_{18}$ and curcumin: $\mathrm{C}_{18} \mathrm{TA}_{18}$ on (a) $3 \mathrm{~T} 3$ cell line and (b) MDA-MB-231 cell line after 24 hours treatment. The data were expressed as means \pm standard deviation $(n=3)$. Data with different small letters within the same group were significantly different $(p<0.05)$ by comparing with $\mathrm{C}_{18} \mathrm{TA}_{18}$. Data with different capital letters within the same group were significantly different $(p<0.05)$ between the same anti-cancer agent treatment. 
Figures

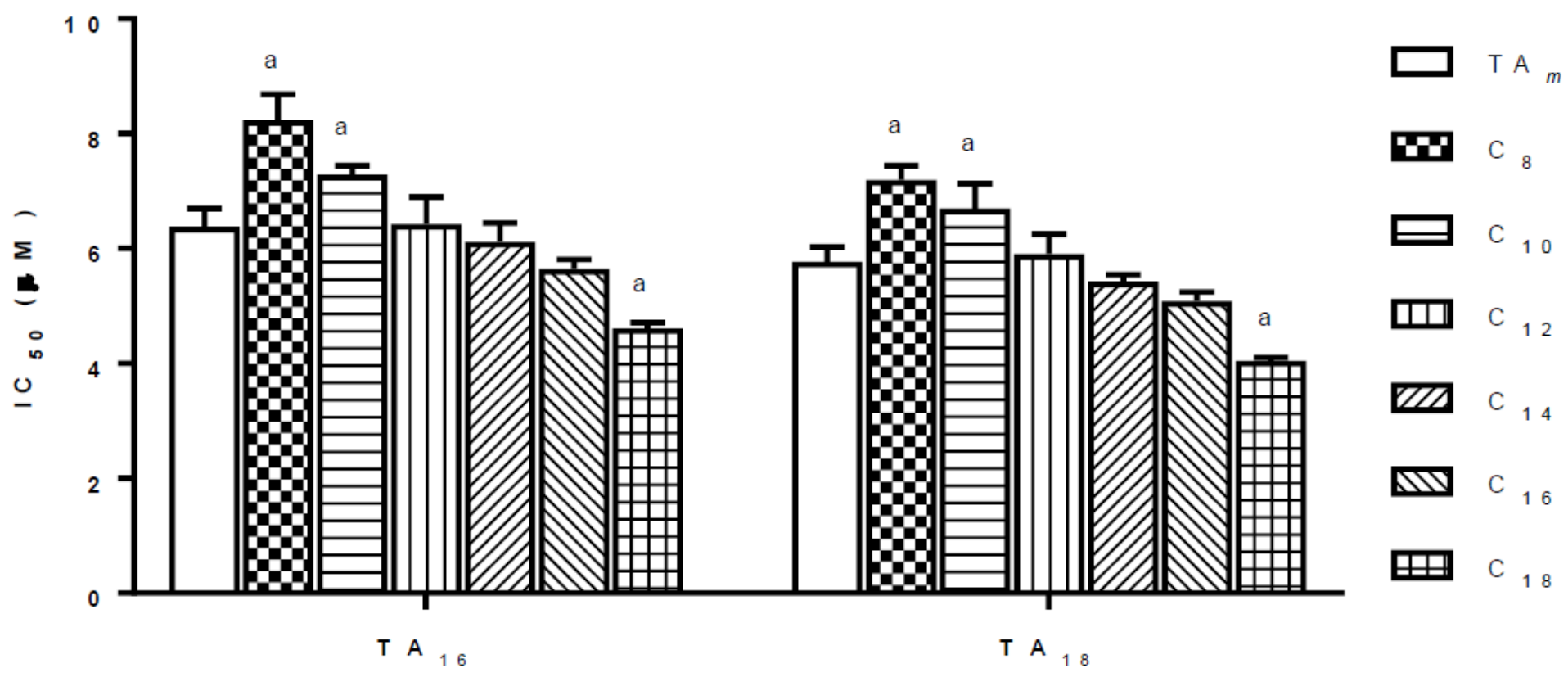

S u r facta $\mathrm{n}$ ts

Figure 1

IC50 of TA16, TA18, CnTA16 and CnTA18 on MDA-MB-231 cell line after 24 hours treatment. The data were expressed as means \pm standard deviation $(n=3)$. Data with different letters within the same group were significantly different $(p<0.05)$ compared with TAm, respectively.



S u r facta $n$ ts

Figure 2 
IC50 of TA16, TA18, C18TA16 and C18TA18 on 3T3 and MDA-MB-231 cell lines after 24 hours treatment. The data were expressed as means \pm standard deviation $(n=3)$. Data with different letters within the same group were significantly different $(p<0.05)$.

(a)

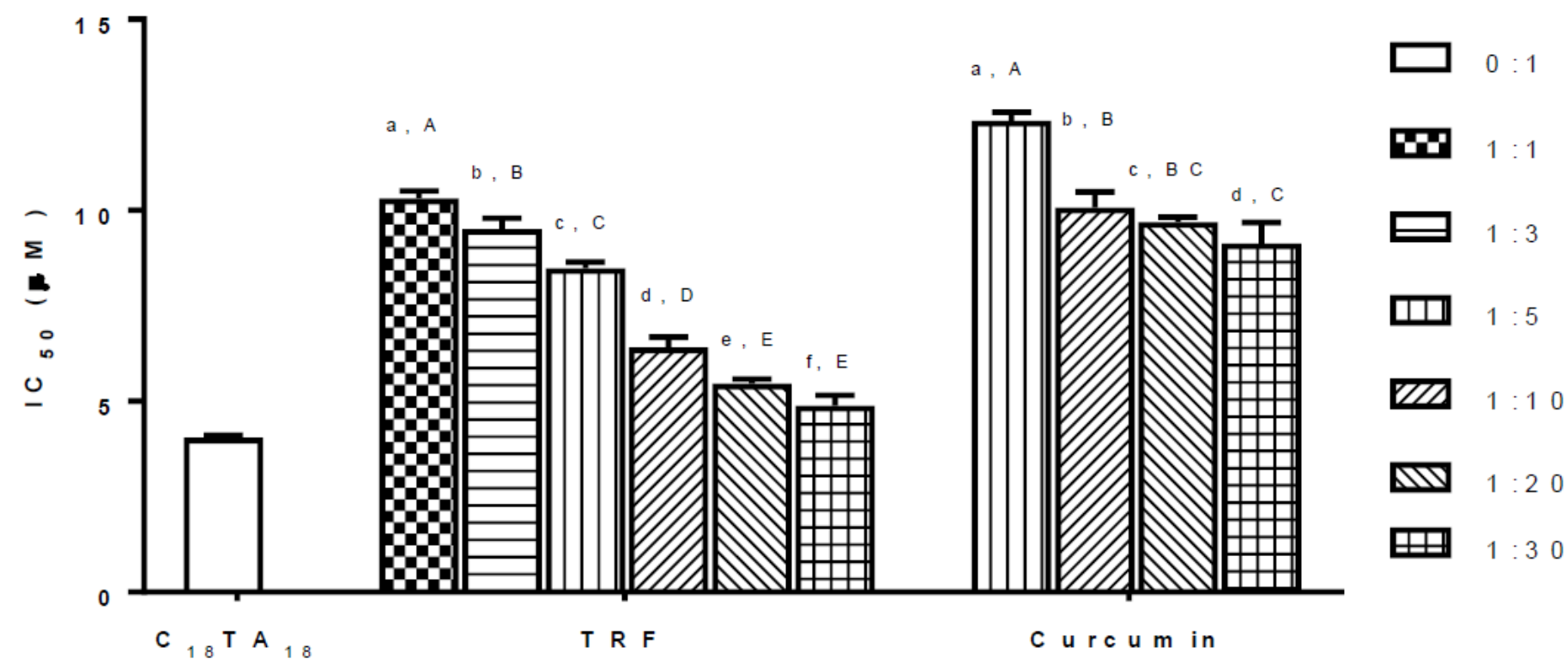

(b)

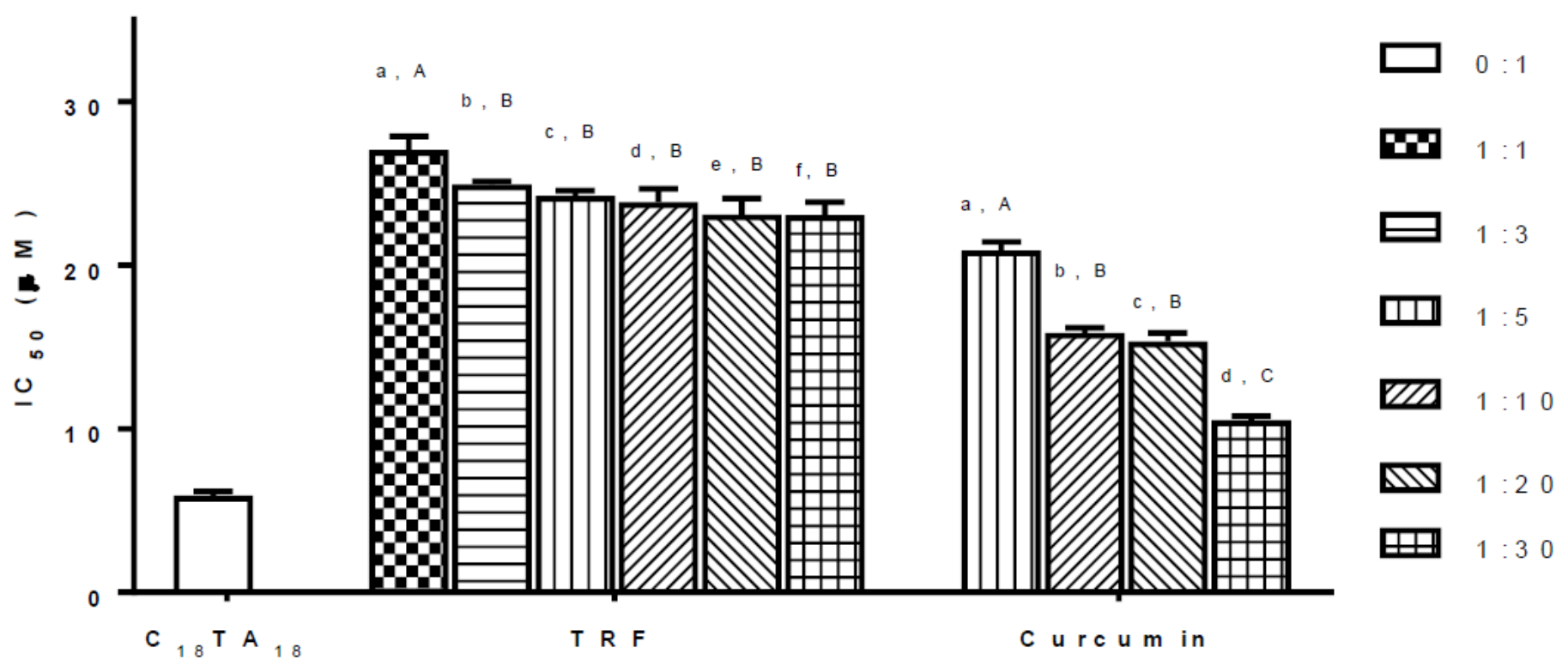

Figure 3

IC50 of TA18, different weight ratios of TRF:C18TA18 and curcumin:C18TA18 on (a) 3T3 cell line and (b) MDA-MB-231 cell line after 24 hours treatment. The data were expressed as means \pm standard deviation $(n=3)$. Data with different small letters within the same group were significantly different $(p<0.05)$ by comparing with C18TA18. Data with different capital letters within the same group were significantly different $(p<0.05)$ between the same anti-cancer agent treatment. 